\title{
Comparing South Texas and Qatari readers' responses to short stories from three cultures
}

\author{
Cathy Downs \\ Texas A\&M University-Kingsville \\ LuAnne Ktiri-Idrissi
}

Austin Community College

\begin{abstract}
Emotional and interpretive responses to three short stories were noted in two study populations of similar age: Qatari students in a post-highschool foundation program preparing to attend branch campuses of western universities located in Qatar, and American students, many of Mexican-American heritage, from a small college in a rural setting in South Texas. It has long been thought that reading literature from a foreign culture confers educational value on the reader; in this investigation the nature of that 'value' was placed under study. Written responses to quiz questions or assignments were used as data; responses critical of or affirming of character, setting, plot, and literary tropes were particularly noted. Our data show that readings from an author whose culture was similar to the reader's created interest and urged both intellectual and affective types of understanding, such as remembering, grieving, healing, forgiving, and feeling pride. Readings from 'classic' literature presented in historical context strongly enabled critical discussion among students in a multicultural setting, since the author's absence from the scene 'allows' free conversation about his or her work without fear of insulting the author's culture. Readings by contemporary writers from outside the reader's culture, or 'multicultural literature', may cause some readers to shy away from the challenge of understanding another culture or to voice stereotypes instead of seeking ideas. Readings from outsider cultures, however, and the affective distancing of 'othering', enable the wellprepared educator and student to discuss how culture patterns our lives.
\end{abstract}

\section{Introduction}

The current study was conceived as a result of observing students in Qatar and in a rural South Texas public university as they read three short stories and discussed how culture was encoded in their readings. Each group read the same three short stories: a contemporary story whose characters and plot were comfortably familiar to South Texas students (and strange or foreign to Gulf Arab students); a contemporary story whose characters and plot were comfortably familiar to Gulf Arab students (and unfamiliar to South Texas students); and a work of canonical western literature written, set, and presented by the instructors as having occurred in the distant past. Students' written reactions to insideculture ideas versus outside-culture ideas were coded. This essay examines three general education/preparatory literature classrooms - one in the United States and two in Qatar - as they readied entry-level students for their more advanced university courses. Western-style multiculturalism is now a longtime part of US students' and teachers' classroom preparation, and the questions which govern this essay are: 
1. What does multicultural practice teach both American students and their contemporaries in Qatar?

2. What values do inside-culture works teach?

3. What place does 'classic' literature have in the classroom, besides celebrating Western cultural norms or providing a window into episodes of Western history?

As a teaching strategy, multiculturalism developed in the US at a time of increased immigration and integration of new Americans into public education systems. Multicultural learning, as it developed in the 1970's and 1980's, included - and includes - using various teaching styles such as cooperative learning to teach learners of multiple cultures, allowing choice in assignments, or exploring languages, traditions, or religions that belong to non-dominant cultures (Banks, 1997). All were developed to embrace a broader cultural 'center'. As education bears the weight of our hopes, certainly multicultural education has borne its share of that weight. It was developed to "build bridges", to "prepare students [for global, not only local, economies]", to "unite diverse groups" (Milner, 2010, pp. 39-40), and to make coursework "meaningful and functional to learners" (Wiley, 1996, p. 51). However, despite attempts to match the teaching force to the ethnicity of students, in the US, most teachers are white, while students of color have come to occupy a greater percentage of the student body in high schools (Cross, 2010, $p$. 207).

Today, those who teach at US universities accredited to prepare tomorrow's teachers are guided by the Conference on English Education's (CEE's) Eight Beliefs for Supporting Linguistically and Culturally Diverse Language Learners, the third of which states:

Socially responsive and responsible teaching and learning requires an anthropologically and ethnographically informed teaching stance; teachers and teacher educators must be introduced to and routinely use the tools of practitioner/teacher research in order to ask difficult questions about their practice.

One suggested practice under this guideline is:

Expect students to read and critique multiethnic and multicultural children's and young adult (YA)

literature (e. g., House on Mango Street; The Color of Water; Miracle's Boys; Uncle Jed's

Barbershop)" (CEE, 2009).

The Texas Higher Education Coordinating Board's (2012) educational outcomes for college literature courses, which have shaped the teaching of the authors of this study, include a Language, Philosophy, and Culture Foundational Component Area which asserts that

(i) Courses in this category focus on how ideas, values, beliefs, and other aspects of culture express and affect human experience.

and

(iii) The following four Core Objectives must be addressed in each course approved to fulfill this category requirement: Critical Thinking Skills, Communication Skills, Personal Responsibility, and Social Responsibility.

The THECB's Core Objective for Social Responsibility states:

(F) Social Responsibility: to include intercultural competence, knowledge of civic responsibility, and the ability to engage effectively in regional, national, and global communities.

Thus elements of the multicultural curriculum are coded into state and national requirements for proficient teaching of language and literature at the high school and college level. 


\section{Context}

\section{Qatar Foundation's Academic Bridge Program: student body and culture}

The Academic Bridge Program (ABP) in Doha, Qatar is a year-thirteen foundation program to prepare top Qatari high school graduates for successful admission and transition to western universities. Entering students must have at least a 75\% high school average. Six American universities, one European university, and a London-based postgraduate institution share Qatar's Education City campus with the Academic Bridge Program. These universities, Qatar University, and other American and United Kingdom institutions represent admission goals for many ABP students.

Still organized largely by tribal affiliations, the small Arabian Gulf country of Qatar is undergoing extremely rapid change driven primarily by oil and gas exploration (Central Intelligence Agency, 2014). In order to move beyond and economy based only on expendable natural resources, the Qatari government is focusing on higher education as a means to sustain prosperity.

During the 2010-2011 academic year, 302 students attended the Academic Bridge Program. Of these, $86 \%$ were Qatari nationals and 14\% were non-Qatari (Qatar Foundation ABP, 2011). During the 20092010 academic year, approximately $25 \%$ of ABP students were accepted to Qatar Foundation Education City universities, $20 \%$ were accepted at UK universities, 5\% were accepted at US universities, and 25\% were accepted at Qatar University (Qatar Foundation ABP, 2010).

Like their counterparts in South Texas (see below), many Qatari students do not enjoy reading. Qatari culture has traditionally valued public recitation and poetry, and silent reading is viewed as a solitary or even an unsociable activity. In Qatari homes with many family members, finding a place to sit quietly to read can be difficult; children are rarely read to and houses may have few books other than religious texts. These facts are changing as the educated population increases; however, many ABP students report that they have never read "a book" in any language. Like the South Texas students with whom they are paired in this study, they have not been required to read extensively in previous courses.

\section{TAMUK student body and South Texas culture}

Founded in 1925, Texas A\&M University - Kingsville (TAMUK) is of medium size. From 2008 data, Hispanic students number about 4000, White students 1500, and Black students 250 (Texas A\&M University - Kingsville, 2010 Table: Enrollment by Ethnicity). Most students are of typical undergraduate age, with 1500 students falling within the <20 age group, and 3000 in the 20-29 age group (Fact Book, 2010, Table: "Enrollment by Age"). Smith's (1986) observations about another population, apply also very well to many TAMUK students' attitudes toward reading. Until recently, among working-class people, limited reading and writing skills were not considered shameful since this was not a cause of poverty (Smith, 1986). Being tagged a reader instead of a doer, especially for a young male, is still considered uncomplimentary in some US cultures (Smith, 1986). Among today's TAMUK students, it is difficult sometimes to bear the label of "intellectual" that becoming a college educated person confers. Reading, therefore, does not lie at the center of South Texas Tejano/a culture.

Most TAMUK students, despite the prominence of Mexican-American surnames among them, cannot speak Spanish. Most students can read in English but not in Spanish. Most write in English when they do write, but avoid classroom writing or reading in any language, except when required (See Appendix A for student profiles). 


\section{Methods}

\section{Overview}

Introductory literature class sections, two from the ABP in Qatar, and one from TAMUK, constituted the study population The research was designed on participant-observer principles. Spradley's (1980) idea of Moderate Participation describes the degree to which the present teacher-researchers interrupted the action they observed through their actual teaching. Such interruptions, in this case, included informing students that they were a study population, defining for them the nature of the study and securing their IRB notices, talking with them about what constituted culture, and sharing with them a list of cultural attributes typical of the overseas students with whom they were paired. Following the cooperative approach (Bogdan \& Taylor, 1975), students were told that, if they wished, they would be part of a study involving another classroom in Qatar, and that their participation could neither add to nor subtract from their grades. Student anonymity has been preserved through use of pseudonyms, in accordance with current IRB protocols.

Students at both institutions were told of their sister cohort on the other side of the globe. At mid-term, students were asked to list some touchstones of their culture such as foods, medical care, family structure, and clothing. These descriptions were condensed by the instructors and sent to the sister cohort class(es) to be shared with the students. Thus, the students under study were made aware of how their own culture was marked by behaviors, clothing, traditions, and food preferences; and they learned, as well, some attributes of the cohort culture.

A modified bottom-up approach enabled the researchers to grapple with the full complexity of data, in the form of student-written short essays. What to code for in students' written analyses of the short stories under study became, for the researchers, a point of negotiation and a moment of discovery and knowledge-creation. In the end, students' writing which remarked on literature's value and which commented specifically on the roles of inside-culture, outside-culture, and classic literature was coded. Because students understood that they were reading the same three short stories.as their cohort group, class discussions informally focused on the nature of the short stories as inside-culture, outside-culture or classic. Each writing prompt also asked students to consider these designations with questions such as "How do the cultural aspects of the story add to or enhance the story?"

\section{Participants}

In Qatar, the total number of ABP students from two different Academic Literature classrooms participating in the study was $n=26$. The ABP students who participated in this research project are all high school graduates who have studied English for 3 to 12 years; most identified as Muslim Arab and the majority had graduated from high school in the Gulf. (see Appendix A for student profiles). Their TOEFL or TOEFL-equivalent scores range from 58 to 109 (advanced to high-advanced). Students at this level are designated as Academic Studies students and the Academic Literature course is a requirement designed to introduce them to the type of critical reading and analysis skills they will need to succeed in their future college classes. Though instruction in English is not new to them, the ABP offers coeducational instruction, which, for most of the students, marks the first time since kindergarten that they have been in mixed gender classes. The classroom methodology is learner-centered and designed to encourage the critical thinking and active student participation required of western-style higher education: yet another departure from the more traditional rote-memorization learning style which most students seemed to have encountered as children. 
The sophomore literature class that is the focus of this study in South Texas is a required general education classes for many majors. After removing from the study students who were less than 18 years of age and those who failed to complete the initial survey in which age data were recorded, 15 TAMUK students from one class participated in the study. Class methodology was learner-centered. Short-term goals of the course were to familiarize students with vocabulary and epistemologies used in literary studies; longer-term and less measurable goals were to expose students to complex scenarios that enable them to reflect on the human condition, both now and in the past.

\section{Data Collection}

The main work of the study was conducted toward the end of the term to enable all students to become practiced in the expectations of the instructor and accustomed to patterns of literary reading and interpretation. For the study, students in both classrooms studied three short stories in succession, and, for each story, answered questions in a free-form short essay. The stories follow a pattern of being 1) from inside the culture of the students - labeled below as Inside-Culture Selection; 2) from the culture of the other student group halfway around the world - labeled below as Cross-Culture Selection; and 3) from a "classic" author who was from neither of the cultures of the two cohort student groups - labeled below as Classic Short Story/Outside-Culture Selection. (Plot synopses of the three stories appear in Appendix B.) Thus, the order of presentation of short stories titles in the two student cohorts was different, with the short story most familiar to the student's culture being offered first. The assignments were as follows:

1. Inside-Culture Selection: Kingsville students read The Moths: written by a California Latina, the story reflects the culture of the Latino students in the class. Qatari students read The Illusion: written by a Bahraini author, the story reflects the Muslim Arab culture of the Arabian Gulf. All students wrote in response to the same assignment:

List the elements in your cultural background that are present in the story. Answer the following in one or two paragraphs: How do the cultural aspects of the story add to or enhance the story? Be sure to provide specific details.

2. Cross-Culture Selection: South Texas students read The Illusion; Qatari students read The Moths. All students responded to the following assignment:

If this story were set in Qatar/South Texas what differences could you anticipate? First, list as many aspects of the story that you can think of including character motivation, etc. that would change. Next, respond to the following in one or two paragraphs: How, in your opinion, did the character's/characters' culture affect the outcome? Be sure to provide examples.

3. Classic Short Story/Outside-Culture Selection: Both sets of students read The Story of an Hour, which is set approximately a hundred years before the students' birth, in New Orleans, USA. The assignment was:

List the similarities and differences between the setting and the culture represented in the story and your own. Be sure to label each item in your list as a similarity or a difference. Answer the following in one or two paragraphs: Could the same outcome occur in South Texas/Qatar today? Why or why not? Be sure to provide details to support your response.

4. Students' Favorite Stories: After having read the three stories, students were asked one more question:

In one or two paragraphs, state which story (The Illusion, The Moths, or The Story of an Hour) you have chosen as your favorite and explain why. Does the culture or setting of the story have any effect on your choice? Finally, write a one-paragraph response to the following question: 
[for South Texas students] Do you think that someone who is not from South Texas would choose The Moths as a favorite? Why or why not?

[for Qatari students] Do you think that someone who is not from Qatar would choose "The Illusion" as a favorite? Why or why not?

Each of the four assignments above includes two types of questions. The first type - let us label it Question A - asks students to identify specific features from the story, often in list format. Question A itself placed students in a mindset to think about how culture patterns literary tropes and to find language to voice their ideas about those tropes. The second type of question - let us call it Question B - asks for interpretive prose responses to literary works. Responses to Question B are signed with students' pseudonyms in the Findings section. Quotations by students below are presented here as written, after minimal correction of spelling and punctuation errors.

\section{Findings}

\section{Inside-culture selections}

(Kingsville students read The Moths; Qatari students read The Illusion)

In the teaching of multicultural literature, assigning inside-culture selections serves to affirm the worth not just of the literary selection, but of the inside culture on the larger map of all cultures. One role of inside-culture literature is to create familiarity between first-generation college students, the instructor, and classroom praxis. Inside-culture literature, the hope is, creates one less hurdle - culturally patterned mores - for classrooms of less enthusiastic readers to clear. Insider literature is a way of adding value to classroom teaching in hopes of retaining reluctant learners and inspiring committed learners.

In the discussions that follow, please see Appendix B for the plot and a brief author biography for each short story. Inside-culture selection Question A reads List the elements of your cultural background that are present in the story.

\section{Kingsville students' responses}

Question A elicited the following most frequent topics, with 10/15 students present and responding:

- Required attendance at Catholic mass by parents (8 students)

- Respect for family elders (5 students)

- Death among family and friends (4 students)

Question B reads, Answer the following in one or two paragraphs: How do the cultural aspects of the story add to or enhance the story? Be sure to provide specific details. Responses concerned 'relating to' the story. A typical response, by student Celina, is:

These elements [of Latino culture] add to the story for me. I feel I relate better to the story because I understand what the author is talking about.

Student Diana voices an effect that many instructors have noticed for some years now:

By adding cultural aspects the reader is able to relate to the story. He or she can even picture themselves in it. It makes the story real.

"Picturing themselves" in a work of fiction is one of the most common deep connections that beginning literature students have to fiction.

Memory can provide a deep connection to fiction, and The Moths revived memories of students' elder relatives. Student Sarah comments: 
I had a family member that was dying. You really start to think, what can you do, or how could you have done better? [...] we all have to die one day, but in this story at least [the grandmother] does not have to die alone.

The Moths enabled students to discuss death and to recall the passing of their own elder relatives. As I learned from a discussion with one student, the short story allowed her to revisit, mentally, an elder's death which she had been unable to confront.

In critical thinking, a goal of college-level literature classes is to set the object of thought at a distance for examination. Student Karen attempts such distancing when she notes the symbolic nature of the moths: "[This story] shows the importance of the moths and how they are the healers of all things".

\section{Qatari students' responses}

The experience of reading literature written by and focused on the life of Gulf Arabs was rare or nonexistent among the student group. Thus, The Illusion worked well because the students are familiar with the class divisions of Arab society ('classism') and privilege granted those of higher status. The humor gave the students permission to take a more critical look at their society. Many were relieved and proud to be given the inside culture reading assignment. They were aware that their student cohort group in Texas was reading The Illusion as a cross-culture reading selection, and the Qatari students expressed hope that the Texans would enjoy the story.

Inside-Culture Selection Question A, List the elements of your cultural background that are present in the story, elicited the following most frequent topics (18/26 responding):

- Special privileges (wasta) given to royalty or wealthy citizens (11 students)

- Classism, both in the story and in Qatari society (8 students)

- Social class expressed through ownership of material goods or through special treatment (7 students)

- Separate medical facilities for women's health (10 students)

- Use of ululation to express joy (8 students)

- Incense used to express welcome in public gatherings (7 students)

Question B reads, How do the cultural aspects of the story add to or enhance the story? Qatari students noted that the setting and society of The Illusion was familiar. Lulwa writes:

It [the setting] made the story much easier to understand because it's almost the same traditions and the same culture [as ours].

Students easily acknowledged the way classism or favoritism pervades their society. Qatar is one of the richest countries in the world (Central Intelligence Agency, 2014), and, indeed, some of the students passing through this program are actually from the Emir's family. Al Jazi states:

[The story] sends a message that social classes play a big role in the author's culture [...] and it explains why they act like that in the story.

In addition, many students add concerns (or critical analysis) about the effects of classism in their society. Hissa writes:

This shows us that people will do anything for those rich people, which is unfair to others, especially in a hospital [...]

Sheikha is able to draw parallels between the characters' actions in the story and similar actions and effects in her society: 
we notice the inequality in the society especially when [the doctor] became nervous and started to give orders to the nurses to empty the room. This also can happen in my culture; people who are rich can control everyone and impose and take advantage of the weakness of others.

Despite their own position as recipients of privilege, many students, upon reading the story, were open to recognizing the effects of classism in Qatari society. Inside-culture stories allow readers to see themselves through the lives of the characters and to feel some freedom to examine the effects of their own traditions and culture.

\section{Cross-culture selections}

(Kingsville students read The Illusion; Qatari students read The Moths)

\section{Kingsville students' responses}

Students did not have difficulty actually reading The Illusion: they had been taught the term 'irony', and they had had experience with hospitals and doctors. However, youthful optimism, as well as their frequent encounters in both school and the mass media with the US Constitution's guaranteed freedom from many types of discrimination, seemed to cause younger students to ignore classism present in American society and to assume that US discourse of equality represented fact rather than ideal.

Question A (If this story were set in Kingsville, what differences could you anticipate?) elicited the following topics, with 13/15 TAMUK students responding:

- Social class and equal treatment (6 students)

- The Hippocratic oath and triage protocols creating strictly equal treatment of all patients in a hospital (3 students)

- People's work ethic propelling them to higher social classes and thus giving them preferred treatment (1 student)

- Hospital room availability to patients of different classes (2 students)

Question B reads: How, in your opinion did the character's/characters' culture affect the outcome? Be sure to provide examples. To engage with the question, students must be able to name elements of a culture and ask whether the themes of the story play within or without the story's dominant culture. Josue, an English major, focused on words and naming conventions that differed between US and Qatari culture, saying, for instance, in the United States, "I would not say 'His Excellency'" (and thus would not even map a verbal picture of privilege).

Karen, Jasmin, Sandra and Stella all remarked that the short story's main theme was one of people receiving medical treatment based on their wealth. Typical comment: "The higher you are on the social ladder, the greater benefits you receive." Caleb noted:

I believe that the culture plays a major role in the swaying of the hospital employees... It's not what you know, it's who you know.

Celina notes, "The character's culture affects the outcome by showing favoritism to those of upper class, or royalty."

Kingsville students could not help but read The Illusion through their own interpretations of constitutional freedoms. Zack found offense in the story's favoritism, since anti-discriminatory rhetoric is a common American trope. One group of students, represented here by Jesús, voiced a trope common to the US culture of self-betterment:

If everyone [in Qatar] were [to practice a culture] like ours, where everyone would have the opportunity to be somebody, then I do not think that [outcome of the story] would have happened. 
Reflections such as these are common in South Texas, where students utter, almost as a mantra, "I can be anything I want to be."

Only one reader, English major Josue, was able to place himself among the objects of irony noted in the author's tale of how the socially unconnected pay elaborate fealty to those with connections: we all "live in an illusion of our own self-worth". His interpretation notes how we are all like the chauffer in the story, wrapped in an illusion of care and worth, while beyond our knowledge, forces are at work to disabuse us of our ideals. For the other students in the course, placing themselves among the objects of irony would be to admit that the American system has its flaws.

\section{Qatari students' responses}

The Moths, written to highlight Latino folk-culture, was difficult for Qatari students to read. The instructor taught the term magic realism to help students understand the final scene ${ }^{1}$. Question A (If this story were set in Qatar, what differences could you anticipate?) elicited these common topics (20/26 ABP students responding):

- Relations among family members which differed from those in American culture (15 students)

- How young women would be shielded from death and dying (5 students)

- How women never walk unchaperoned in public (5 students)

- How openly questioning the importance of religion is quite uncommon (5 students)

- How the outdoors in general and moths in particular are hot, unpleasant, dirty (2 students)

- How family discord is either disallowed or unspoken (3 students)

Question B reads: Next, respond to the following in one or two paragraphs: How, in your opinion, did the character's/characters' culture affect the outcome? Be sure to provide examples. Qatari students were quick to recognize the cultural elements present in The Moths and many came up with a lengthy list of differences. Some of their responses contained judgments such as: "Less faith in religion vs. more faith in religion," "bad relationship with family vs. good relationship with family."

The instructor notes that students were aware that their comments might be shared with others and wanted to put their own culture in the best light. Other student comments were a bit more open, however; for example, "granddaughter doesn't care about religion" vs. "even if she doesn't care she would have to practice it and not say anything."

The open-ended questions asked students to comment on the significance of the cultural setting. The responses indicate the students did understand the importance cultural setting had on the outcome of the story. Hoda notes the universality of the theme in her comment:

It is true that culture can change a person's thoughts and opinion but culture does not change one's feeling towards death...

Safa sees a practical cultural element that would change the entire outcome of the story:

I don't think that grandmother would have died at the end of the story if it would happen in Qatar. Because a granddaughter at the same age here in Qatar would certainly have called her parents...

\section{Classic short story/outside-culture selection}

(all students read Story of an Hour)

American author Kate Chopin's 1896 tale The Story of an Hour fits a profile we felt we needed to include in this assignment: a work foreign to both cultures, so that we could observe all our students grappling with a short story set far from them in time. Any nineteenth-century story in English could have been 
chosen for this role; Chopin's tale, frequently anthologized, has an ironic twist that allows the teaching and practicing of the literary term irony.

\section{Kingsville students' responses}

For Kingsville students, reading a 'classic' work was what one does in literature courses. Observations were open and freely given; the frequent practice in their secondary schooling of commenting on classic literature put them at ease. Question A (List the similarities and differences between the setting and the culture represented in the culture and your own) elicited these topics (9/15 TAMUK students responding):

- How women today are freer to shape their lives (6 students)

- How advanced medical technology and communications would render the story moot today (5 students)

- How our longing for better lives creates frustration or foolhardy actions (4 students)

- How large-scale disasters and terrorism keep this story still applicable today (1 student

Question B reads: Answer the following in one or two paragraphs: Could the same outcome occur in South Texas today? Why or why not? Be sure to provide details to support your response. Kate Chopin was not presented to students as living, or as a South Texan or Latina (she was none of these things). Perhaps her absence in fact, or her absence from any category with which they were familiar, led students to discuss the protagonist's choices quite freely. The story generated multiple threads of conversation.

Kristina noted, in an important strand of the class discussion:

In reality this [unfulfilling marriage] does happen everywhere. People do not know how to find happiness

Damek critiqued our entire culture's focus on marriage as a lifestyle choice, noting:

I have known and met countless amounts of people who are in marriages that leave them lifeless. I feel that, as a culture, we have too many factors that push this [marriage on people who should not marry]. My number one example is religion [that urges both marriage and faithfulness to a spouse].

Although there are still unhappy marriages today, Alejandra reminds readers that divorce is now easier to obtain: "Unhappy couples choose to split up instead of tolerating each other," and thus this story would be less likely to happen in the US today.

Only one student among the Kingsville cohort, Stella, examined the women's rights angle (students in Kingsville reflect other US students who have come to hold discussion of women's rights as something the class should avoid):

[Although there are] common cases of domestic violence [... that cause women to want to leave marriage] I believe it would not ever be accepted again for men to be so controlling over a woman.

Several students examined how people encounter and handle disaster. One student (Sarah) examined the phenomenon of meeting disaster with no mediation, no warning or information to cushion the shock: "When something happens to us in life when we have our back turned, it shocks." Karen notes

In this case [which I saw in the news] there were two mistaken identities. The family that had thought that their daughter had died later found out that she was alive.

Two students found a kind of comfort in noting that our technologies seem to offer a modicum of protection from surprise. Araceli writes: "There is a lot more technology today that allows people to identify victims through DNA." Jesús notes that, in breaking bad news, officials take it upon themselves 
to control and moderate shock: "We try our best not to notify the family until we are sure [of the identity of victims]". Alejandra focused on an idea cited several times during our study of the short story, and that is that modern people have more control over death and dying:

Through the vast power of today's media, it is more likely that Mrs. Mallard would find out about the accident through the news, Internet, or phone.

\section{Qatari students' responses}

The instructor and students explored Victorian culture in America together, noting how Mrs. Mallard would have had to rely on her husband's income while caring for the home. Question A (List the similarities and differences between the setting and the culture represented in the story and your own) elicited the following most common topics, with 19/26 ABP students responding:

- Rising incidence of divorce in Gulf culture (6 students)

- Mrs. Mallard's musings on freedom after her husband is reported dead (4 students)

- Incomprehensibility of being unhappy in marriage (4 students)

- How a widow in Qatari culture would lose her place in society (4 students)

Question B reads: Could the same outcome occur in Qatar today? Why or why not? Be sure to provide details to support your response. Most students drew obvious parallels between American marriages of 100-plus years ago and marriages in Qatar today. Though The Story of an Hour contains many cultural differences as noted by Qatari students, the central theme of freedom, particularly the freedom of women in marriage, is a timely concern for young adults in the Arabian Gulf. Qatar is experiencing a rapidly rising divorce rate with over 1 in 3 marriages now ending in divorce. In a society that highly values family, divorce is especially hard on women and children, since social status and income-earning comes largely through a family's men.

Female students were quick to understand Mrs. Mallard's unhappiness with the constraints of her traditional marriage. Al Jazi wrote:

Women now still hide their feelings and take all the pressure of the family life, and most women do that because they are afraid of the social system; that prevents them from getting their freedom.

Some students thought the lives of Qatari women had changed significantly and that women no longer felt they must silently suffer in an unhappy marriage. Ali, one of the few male students to comment on women's freedoms, notes:

Recently Qatar has developed rapidly and that affected also the culture and made such a big difference. Nowadays women are very strong

Maryam also feels that

women in Qatar today have more freedom and a way in expressing their opinion unlike Mrs. Mallard who was so suppressed that she got happy when she heard that her husband died.

Many Qatari students, however, focused on a widowed woman's plight and noted that a widowed woman in Qatar could end up in a much worse situation after the death of her husband. Buthaina states:

In Qatar a woman is not free after the death of her husband because she returns to the responsibility of her brothers or her parents if she does not have any children. Her woman's rights will still be restricted.

Similarly, Noura writes: 
In Qatar there is [only] a slight chance for the women to have the freedom when her husband dies.

She would be very depressed because she knows that her husband is all she has.

Even though Qatari students understood the feelings of freedom a woman could imagine by escaping from a controlling husband, they could not imagine that this freedom would stretch into "Spring days and summer days, and all sorts of days that would be her own" (Chopin). The Qatari students' believed that life for a widowed woman would not be one of newly found freedom. Their understanding of the possible outcomes of an unhappy marriage is an example of how an outside culture/classic reading can lead to interpretations that are particular to a specific culture

\section{Students' favorite stories}

The last question reads: In one or two paragraphs, state which story ("The Illusion," "The Moths," or "The Story of an Hour") you have chosen as your favorite and explain why. Does the culture or setting of the story have any effect on your choice? Finally, write a one-paragraph response to the following question: [To South Texas students] Do you think that someone who is not from South Texas would choose "The Moths," or, [to Qatari students] Do you think that someone who is not from Qatar would choose "The Illusion" as a favorite? Why or why not?

When students were asked to name their favorite story, overwhelmingly they voted for the insideculture story. Their familiarity with the mores portrayed dominated their thoughts concerning their choices. In both Qatar and Kingsville, $20-25 \%$ of students did favor Story of an Hour, while about $15 \%$ in each group preferred the cross-culture reading. The statistics, as always, do not tell the whole story. Students' thoughts about the function of insider and outsider literature show that an insider does not have to have been born within a culture to understand or appreciate that culture, and thus, race, primary language, or gender are not always reliable markers to aid teachers in choosing works for a course.

\section{Kingsville students}

The Moths, the clear favorite in South Texas, was enjoyed as a mirror of some students' own lives and as a tale whose moral universe seemed complete. Student Josefina experiences "The emotion and memories of my childhood" [by reading The Moths], despite having grown up in Detroit. Sandra, a very thoughtful political science major with Hispanic roots in Kingsville, finds "The Moths takes me back to the beginnings of my own spirituality." Kristina, a South Texas Latina parent in her 50 s sees in The Moths a kind of justice, or cycle of helping; the infant is helped by its parents; the grown child helps its dying elders: "In the Hispanic culture we try to take care of our elderly parents." The Story of an Hour was rated as the second-most favorite story in Kingsville. Jesús, a quiet-spoken, intellectually gifted student from near the Mexican border, identified Kate Chopin as a New Woman. Jesús had studied New Women and the Aesthetic movement in his previous schooling; this short story fit into his newly learned schema and ratified his intellectual accomplishment.

When further asked Do you think that someone who is from Qatar would choose "The Moths" as a favorite? Why or why not?, students seemed to fall into two camps. One was that culture plays a very important role in students' understanding of what they read. For these students, reading The Moths aroused their memories of growing up, and likewise, they could not see how someone outside the culture could understand a story from such an insider perspective. Anglo-American student Karen, a mother who grew up in South Texas, felt that she had applied an acquired knowledge of South Texas Latino culture: 
Culture does have an effect on my choice because, living in South Texas, we always got to hear about the Spanish customs [...]. Yes, my culture has an effect on why I chose this story [...] I understand it. I can relate to it.

Similarly "My Hispanic culture from North Texas isn't as strong, but I understand the culture [of the short story]," declares psychology major Celina. Josefina, whose Hispanic roots are from the Midwest, writes:

People that have a culture similar to that of Hispanic would choose The Moths regardless of where they come from.

A smaller group of students felt that experiencing reading as pleasurable does not have to be tied to the reader's culture. Diana, whose Hispanic background is intermingled with French and English culture, did not think culture has anything to do with her choice of The Moths. She writes: "I grew up spending half my year in Vermont, and half in South Texas." Jesús declares: "I am from South Texas and I did not choose The Moths as my favorite." A few students asked themselves if there were a form of "world culture" or "world understanding" that enables all people to share ideas: Josue, the honors English major, notes:

I found The Illusion most entertaining, and its comment, not just on one culture, but the whole of the world.

Alejandra, a thoughtful senior sociology major, writes: "All of the stories can be translated to many cultures". In sum, there are as many lost, abused women, like the main character in The Moths, all over the world, as there are unhappy women like the main character in Story of an Hour.

\section{Qatari students}

The majority of students predictably chose the inside culture reading selection as their favorite. Qatari students' reasons for choosing the inside culture selection, The Illusion, referred to familiarity and comfort. "It talks about something that happens almost every day in my country," writes Nour. Safa explains her choice by sharing that the story was

very easy to read and understand [...] for example [...] names play a big role in our society [...] 'Al-

Dhahab' in Arabic means 'the gold,' which certainly shows how important or what a big personality this character [in The Illusion] has.

Surprisingly, the reasons given for outside culture choices also refer to elements of story that the students could relate to. In choosing The Story of an Hour Suad writes:

She didn't want to get back to her self-prison.[...] I'm also not the kind of person who could live happy if I wasn't free.

The cross-culture selection was chosen by a few students in each cohort group, but the instructor notes that it was the academically high-performing students who made this less popular choice. Hissa, who chose The Moths as her favorite shares that "I don't get along very well with my sisters just like the girl in the story" and "The girl in the story was not pretty. [...] She's just like me".

When Qatari Students answered the second prompt, Do you think that someone who is from South Texas would choose "The Illusion" as a favorite? Why or why not? Their desire for the rest of the world to understand them sympathetically stood out. As they discussed their favorite stories, they expressed hope that Arab literature might be a kind of ambassador for their world.

Half of the Qatari students thought that the cohort group in South Texas would choose The Illusion as their favorite. This was a surprising result because the majority of Qatari students favored their own inside culture selection. According to the students, The Illusion was easy to understand and featured 
events that happened every day in their own culture. A closer look at why they thought South Texas readers would favor The Illusion is useful. A number of students wrote comments similar to Buthaina's:

It would tell them [South Texans] some facts about the Gulf and the different culture and traditions to see if they can compare it with theirs. It would also make them see the Gulf from a different perspective and find it interesting.

Nour notes that "These kinds of things happen in all different countries in the world." Qatari students, in choosing the Arab story for their South Texas cohorts, may display, as well, loyalty to their own culture, or perhaps even inability to see beyond it.

The other half of the Qatari students correctly predicted that their South Texan cohort would not choose The Illusion as a favorite. Hoda's comment shows an understanding of the nature of inside culture reading selections:

They will choose The Moths [...] because it's closer to their culture and traditions and it would be easier for them to understand.

Conversely, Suad expresses the problem with cross-cultural reading selections:

They won't get the deep layers [...] because you have to live in the same culture to know how it is. I think everyone tends to choose the story that's similar to their culture.

\section{Conclusions}

\section{The affective dimension and student engagement}

There is much research showing that students who read within their culture may find that reading opens a path to deep feeling. Cohen (2007) shows how struggling readers find motivation when they believe that reading applies directly to their lives. Dirkx (2008) notes how important engaging the affects is to educating the whole person among adult students. Deep engagement in learning can best be achieved by including affective engagement (Connor, 2009) in learning. Czikszentmihalyi (1990), in his study of optimal mental states, notes that "sometimes even one word is enough to open a window on a new view of the world" (p. 117); the same author also notes, however, that difficulty is a necessary ingredient in optimal experience (Czikszentmihalyi 1990). Engagement, not merely the threat of a poor grade, is important for readers' success in their literature courses among students for whom reading, for one reason or another, is seen as a negative experience.

We note that the works of fiction most cherished by students in our study were insider works. Students responded to these in emotionally, intellectually, and morally rich ways. László (1999) notes that such a response causes us to define literature as something beyond required reading material. For our students, a work may seem a requirement or a curiosity until, for them, it encodes the home culture in a way that images that culture back richly. In reading insider works, students do more than parse words. Reading is an act of recalling, building 'images' of sight, smell, and sound. Reading is extended in students' own memories until it becomes the prequel or sequel to their own life-stories. "When I was in the hospital...," one student might begin to tell, in fact rewriting the ending to The Illusion. "My grandmother...," another begins, and in so beginning, becomes a writer of her own version of The Moths. The insider fiction affirms one's own life and make it seem as if one's life were heroic or storied. Thus lesson plans or syllabi that attempt to match works of literature with the student population enable the reader to, in essence, write or mythologize his or her own culture. 
A few Qatari students noted that the cultural elements of their favorite story, The Illusion, would certainly be familiar to Arab/Gulf people but perhaps not to readers from other cultures. This is most clearly expressed by Suad:

If someone read the story, they would directly notice that it takes place in an Arab country, Gulf country specifically. If you gave the same story to a non-Arab student to read, for sure they will understand the words, but they won't get to what's behind them.

Suad refers to the fact that the names in The Illusion hint at each character's socioeconomic class and thus his or her future. Kingsville students did not and could not parse Arabic names, hence, Qatari 'insider' short fiction was 'outsider' fiction among English-speaking Kingsvillians.

The outcomes of the present research uphold the idea that assigning insider literature, literature that encodes markers of a particular culture in its language, is a powerful force in teaching groups of that culture. When affect is deeply engaged and the task assigned holds a reasonable level of difficulty, the outcome "unite diverse groups" might be achieved; however, the group united would be the members of the literary class: specifically, teacher and students might find common ground and respect. Students probably cannot find instant unification, through literature alone, with other cultural groups.

\section{Pitfalls for the unwary teacher of multicultural literature}

We anticipated that cross-cultural readings would allow students to draw parallels between cultures and that students might note the universality of human experience. For the most part, however, we were wrong. Our study's cohort groups share many similarities, but their cultural backgrounds and worldviews are very different. Our study took place during attacks on Iraq and Afghanistan by the United States; Saddam Hussein had been executed, but Osama bin Laden was still at large. Students in the Kingsville classroom had relatives in the military; to these, Muslims could represent the enemy. To some Qatari students, Westerners represented the aggressors.

Many Kingsville students, immersed in the US rhetoric of freedom, could not see the inequalities perpetuated by US culture, nor could they imagine themselves partaking in the creation of inequality. The Illusion's overt treatment of inequality resulted in students' 'wrapping themselves in the flag' rather than critically examining their own culture. Although US students clearly understood The Illusion, by and large many of the affective dimensions available to Qatari readers of The Illusion did not obtain for the US students. Kingsville students could not adequately "bridge" between cultures, gain "intercultural competence" (in the parlance of the state education agency's desired outcome for a general education literature course) or feel "united" with Qatari students.

Conversely, Qatari students were outwardly proud of their culture and aware of how they were portrayed in the Western media. As readers of multicultural literature they tended to analyze the insideculture reading of The Illusion in a sparing and kind light. The instructor often sensed that they were speaking and writing in a public voice and not always sharing or discovering the levels of meaning that the author had intended. When approaching the cross-cultural reading The Moths, however, the crosscultural comparisons often turned to judgments that put Qatari culture in a good light and American Latino culture in a negative light. In the case of Qatari students, The Moths seemed to lead them away from the instructor's desired classroom outcomes. When The Moths was taught to Qatari students, its strangeness to their culture subverted messages which the story holds for Latino readers about navigating the passage between independence and family-orientation. In today's critical language, most Qatari students lacked schemata (see, e.g., Rumelhart, 1980) with which to interpret The Moths. The idea of a young girl walking outdoors by herself as the protagonist in The Moths did is culturally 
unacceptable in Qatar. Students read her actions as those of someone not adequately protected by adults. The cross-cultural readings revealed how, for both cohort populations,

Listeners must, in order to store and recall narratives, be able to anticipate some order; [... They must share] specific socio-cultural knowledge. (Heath \& Blandscomb, 1986, p. 17)

Guy's (1999) comments are also applicable:

To the extent that classroom materials do not relate to learners' life experiences, these materials become irrelevant and ineffective (pp. 15-16).

Students' inability to engage, or even their sense of outrage, as revealed in some of their written comments, means that such outcomes as "to unite diverse groups" "build bridges" or gain "intercultural competence" were subverted in both populations.

The inclusion of multicultural reading assignments is not always a noble undertaking. In fact, pitfalls abound for the unwary teacher of multicultural literature. Some uncomfortable moments occurred in both cohort classrooms as students voiced their biases and judgments about disparate cultures. On one level these cross-cultural missteps interfere with insightful, critical reading. On another level, multicultural literature selections bring biases to the forefront, allowing instructors and students to examine the nature of the 'outside' or 'cross-cultural' world that surrounds us all. Instructors who teach multicultural literature must be prepared to handle open expressions of bias, dislike, or confusion; their purpose for teaching such readings - and the way they plan on handling disagreement - should be quite clear in mind before proceeding.

Despite misreadings of the cross-cultural selections, a handful of the most capable students in each cohort were able to draw meaningful parallels between cultures and to recognize a universal human experience as we discussed the cross-cultural readings.

The classic short story/outside-culture selection The Story of an Hour served as a valuable bridge to understanding and critical thought. Both the women's rights angle of The Story of an Hour and social inequality in The Illusion could be parsed in the two cohort classrooms, thus opening conversations about how literary irony is a tool often used to expose cultural or social conflict. In exercises where students were asked whether the story they were reading could become reality where they lived, a few said yes and explained how. To our minds, the acts of entering the fictional world in the imagination, then turning the psycho-social or moral mirrors of fiction on themselves, are strengths borne by literature and other imaginative works that cannot be borne as easily by disciplines whose goal is to avoid affective display in order to more fully reveal fact.

\section{Final comments}

We return to the basic question that this project sought to explore: What value do multicultural reading selections convey? The outward answer is that readings from familiar cultures create warmth and comfort in the classroom for those students whose culture they reflect; readings from unfamiliar cultures are easily misinterpreted or under-appreciated, and do not consistently advance recent statemandated goals. 'Classic' literature does hold a place in classrooms. Since the authors of such works are no longer among us, 'classic' works do not create fear among the students that they will insult members of the writer's culture. Discussion, therefore, may be relatively unencumbered.

Cross-cultural reading selections do produce insightful analysis from a handful of the brightest, or most receptive students in Kingsville, Texas and Doha, Qatar. However, 'average' students may find the crosscultural work so dissonant as to interfere with both teaching and learning. 


\section{For further research}

The current research sprawls across two continents and multiple cultures; at times teasing meaning from so many variables was difficult. Two strands of thought for future research come immediately to mind. Firstly, what students expect from a literature course is culturally formed, and this expectation shapes outcomes (See Appendix A for students' expectations of literature classes). Further research may clarify dissonance between state-mandated outcomes and student expectations. Secondly, universitybound Arab students have a special need: a literature of their own. That literature exists, but for university populations in the Gulf an anthology of Arab short fiction and poetry appropriate for mixedgender classrooms is a useful goal.

\section{References}

Abd Al-Malik, M. (2005). The illusion. S. Jabsheh \& N. Shihab Nye (Trans). In S. Jayyusi (Ed.), Modern Arabic fiction: An anthology (pp. 141-143). New York, NY: Columbia University Press.

Banks, J. (1997). Multicultural education: issues and perspectives. Boston, MA: Allyn and Bacon.

Bogdan, R., \& Taylor, S. J. (1975). Introduction to qualitative research methods: a phenomenological approach to the social sciences. New York, NY: Wiley.

Central Intelligence Agency (2014). The world factbook: Qatar. Retrieved from https://www.cia.gov/library/publications/the-world-factbook/geos/qa.html.

Chopin, K. (2006). The story of an hour. In S. Marcus (Ed.), A world of fiction: Twenty timeless stories (pp. 14-16). Switzerland: Pearson Education.

Cohen, J. (2007). A case study of a high school English-language learner and his reading. Journal of Adolescent and Adult Literacy, 51(2), 164-175.

Connor, J. (2009) Student engagement in an independent research project: the influence of cohort culture. Journal of Advanced Academics, 21(1), 8-38.

Conference on English Education. (2009). Position paper: Supporting linguistically and culturally diverse learners in English education. Retrieved from http://www.ncte.org/cee/positions/diverselearnersinee/contenthistory.

Cross, B. (2010). Messages to teacher educators from the margins: teachers of color on equity in diverse classrooms. In Milner, H. R. (Ed). Culture, curriculum and identity in education (pp. 207-222). New York: Palgrave Macmillan.

Csikszentmihalyi, M. (1990. Flow: the psychology of optimal experience. New York, NY: Harper.

Dirkx, J. (2008). The meaning and role of emotions in adult learning. In J. Dirx (Ed.), Adult learning and the emotional self (pp. 7-18). New directions for adult and continuing education 120. Hoboken, NJ: Wiley Periodicals.

Guy, T. (1999). Introduction. In T. Guy (Ed.), Providing culturally relevant adult education: A challenge for the twenty-first century (pp. 1-18). Ser. New directions for adult and continuing education 82 . S. Ed. S. Imel. San Francisco: Jossey-Bass.

Heath, S. \& Blandscomb, A. (1986). The book as narrative prop in language acquisition. In B. Schifflin \& P. Gilmores (Eds.), Literacy: Ethnographic perspectives (pp. 16-34). Ser. Advances in discourse processes 21. Ed. R. Friedler Norwood, NJ: Ablex. 
László, J. (1999). Cognition and representation in literature: the psychology of literary narrative. Budapest: Akademiai Kaidó.

Milner, H.R. (2010). Culture, curriculum and identity in education. New York: Palgrave Macmillan. Qatar Foundation Academic Bridge Program (2011). Admissions and Records Office report. Unpublished document.

Qatar Foundation Academic Bridge Program (2010). Final University Admissions Report. Unpublished document.

Rumelhart, D. E. (1980). "Schemata: the building blocks of cognition." R. Spiro, B. Bruce \& W. Brewer (Eds). Theoretical issues in reading comprehension (pp. 33-58). Hillsdale: Lawrence Erlbaum.

Smith, David M. (1986). Anthropology of literacy acquisition. In B. Schifflin \& P. Gilmores (Eds.), Literacy: Ethnographic perspectives (pp. 261-275). Ser. Advances in discourse processes 21. Ed. R. Friedler Norwood, NJ: Ablex.

Spradley, J. (1980). Participant observation. New York, NY: Holt, Rinehart, and Winston.

Texas A\&M University-Kingsville (2010). Factbook. Retrieved from

http://www.tamuk.edu/oir/fact_book/index.html

Texas Higher Education Coordinating Board. (2012). Texas language, philosophy, and culture foundational component area. Retrieved from http://www.thecb.state.tx.us/index.cfm?objectid=6ACB8C9B-04BA-86F7-F883B7872939769E

Viramontes, H.M. (1998). The moths. In Oates, J. (Ed.), Telling stories: An anthology for writers (pp. 628632). New York: Norton.

Wiley, T. (1996). Literacy and language diversity in the United States. Language in education 87. McHenry, IL: Center for Applied Linguistics/ Delta Systems. 


\section{Appendix A - Student profiles (self-reported)}

Texas A\&M University-Kingsville Student Characteristics $(\mathbf{N}=15)^{2}$

\begin{tabular}{|c|c|c|c|c|c|c|}
\hline Student $^{3}$ & Major & $\begin{array}{l}\text { Level } \\
\text { of Uni- } \\
\text { versity } \\
\text { Study }\end{array}$ & Age & $\begin{array}{c}\text { First } \\
\text { language }\end{array}$ & Ethnicity & $\begin{array}{l}\text { Literature's worth, } \\
\text { as defined by the student }\end{array}$ \\
\hline Celina & PSYC & 4 & $23-28$ & English & Hispanic & Could help with her major \\
\hline Araceli & SPAN & 4 & $23-28$ & Spanish & Mexican & $\begin{array}{l}\text { Literature helps in language } \\
\text { learning; }\end{array}$ \\
\hline Caleb & MATH & 3 & $23-28$ & English & Anglo & $\begin{array}{l}\text { Literature is a history and a map for } \\
\text { the future since history repeats itsel }\end{array}$ \\
\hline Jasmin & CSDO & 2 & $18-22$ & English & Hispanic & $\begin{array}{l}\text { Learning how people other than } \\
\text { oneself think is helpful for dealing } \\
\text { with the public. }\end{array}$ \\
\hline Diana & ENGL & 2 & $29-50$ & English & Mixed & Love of reading and writing \\
\hline Kristina & SoW & 3 & $29-50$ & Spanish & Hispanic & $\begin{array}{l}\text { Helps her understand different } \\
\text { cultures, important to her major }\end{array}$ \\
\hline Sarah & ME & 2 & $18-22$ & English & Anglo & To better oneself \\
\hline Josefina & Ed & 1 & $23-28$ & English & Hispanic & Helps with everyday life \\
\hline Karen & INTD & 2 & $23-28$ & English & Mixed & $\begin{array}{l}\text { Insight into history and into the } \\
\text { ways that other people } \\
\text { think/thought and live/lived }\end{array}$ \\
\hline Sandra & POLS & 3 & $18-22$ & English & Hispanic & $\begin{array}{l}\text { Literature should be part of } \\
\text { everyone's life }\end{array}$ \\
\hline Emilio & PHARM & 1 & $18-22$ & English & Hispanic & $\begin{array}{l}\text { Literature could help with my major } \\
\text { because I will learn about things I } \\
\text { am unfamiliar with. }\end{array}$ \\
\hline Stella & PSYC & 3 & $18-22$ & English & Bi-racial & $\begin{array}{l}\text { Literature carries meaning; it helps } \\
\text { people think critically in ways they } \\
\text { had not before }\end{array}$ \\
\hline Jesus & ENGL & 2 & $18-22$ & English & Mexican & $\begin{array}{l}\text { Books can spread his culture to } \\
\text { those of other cultures; books } \\
\text { enable culture to be encoded for } \\
\text { future generations }\end{array}$ \\
\hline Alejandra & SOC & 4. & $23-28$ & Spanish & Hispanic & \\
\hline Damek & HIST & 1 & $18-22$ & English & Mixed" & $\begin{array}{l}\text { Important for research, for personal } \\
\text { reasons }\end{array}$ \\
\hline
\end{tabular}


Qatar Foundation Academic Bridge Program student characteristics ( $N=26)$

\begin{tabular}{|c|c|c|c|c|c|c|}
\hline Student & Major & $\begin{array}{l}\text { Level } \\
\text { of Uni- } \\
\text { versity } \\
\text { Study }\end{array}$ & Age & $\begin{array}{c}\text { First } \\
\text { language }\end{array}$ & Ethnicity ${ }^{4}$ & $\begin{array}{l}\text { Literature's worth, } \\
\text { as defined by the student }\end{array}$ \\
\hline Hasna & COMJ & Pre & $18-22$ & Arabic-Eng & Muslim Arab & Help with College Applications \\
\hline Noura & POLS & Pre & $18-22$ & Arabic, Eng & Muslim Arab & Very useful (?) \\
\hline Ali & BUS & Pre & $18-22$ & Arabic, Eng & Muslim Arab & \\
\hline Nassir & BUS & Pre & $16-17$ & Arabic & Muslim Arab & $\begin{array}{l}\text { Helps with speaking and } \\
\text { writing }\end{array}$ \\
\hline Al Jazi & COMM & Pre & $16-17$ & Arabic & African & Helps because I love to write \\
\hline Reem & BUS & Pre & $16-17$ & Arabic & Muslim Arab & Help with communication \\
\hline Hiya & BUS & Pre & $16-17$ & Arabic & Muslim Arab & Improve my English \\
\hline Maryam & COMM & Pre & $16-17$ & Arabic & Muslim Arab & Yes \\
\hline Hasna & COMM & Pre & $18-22$ & Arabic, English & Muslim Arab & $\begin{array}{l}\text { Helps with applications to } \\
\text { universities }\end{array}$ \\
\hline Abdulaziz & ENGIN. & Pre & $16-17$ & Arabic & Muslim Arab & $\begin{array}{l}\text { Helps with communication } \\
\text { and with TOEFL }\end{array}$ \\
\hline Amna & COMM & Pre & $18-22$ & Arabic-English & Muslim-Arab & Will have to read a lot \\
\hline Muna & ART & Pre & $18-23$ & Arabic, English & Muslim Arab & $\begin{array}{l}\text { Improve reading speed and } \\
\text { vocabulary }\end{array}$ \\
\hline Alanood & $\mathrm{EE}$ & Pre & $18-24$ & Arabic, English & Muslim Arab & Don't Know \\
\hline Buthaina & COMM & Pre & $18-22$ & Arabic & Muslim Arab & \\
\hline Manal & MD & $\mathrm{Fr}$ & $18-22$ & Arab Berber & African & Develop English Skills \\
\hline Lulwa & BUS & Pre & $18-22$ & Arabic & & Beneficial for her major \\
\hline Safa & COMJ & Pre & $18-22$ & Arabic & Arab & The fun of reading \\
\hline Hoda & BUS & Pre & $18-22$ & English & Arab & \\
\hline Hissa & ART/BUS & $S$ Pre & $18-22$ & English & Arab & $\begin{array}{l}\text { To read and write more } \\
\text { properly, to build vocabulary }\end{array}$ \\
\hline Jassim & CIVE & Pre & $18-22$ & English & Arab & $\begin{array}{l}\text { Reading forces this student to } \\
\text { think further than } \\
\text { appearances; helps in drawing } \\
\text { conclusions }\end{array}$ \\
\hline Sheikha & MD & Pre & $18-22$ & Arabic & African & $\begin{array}{l}\text { To teach about cultural } \\
\text { history, to improve writing } \\
\text { and communication. }\end{array}$ \\
\hline Hamad. & POLS & Pre & $18-22$ & German & European & Politics requires a lot of \\
\hline
\end{tabular}

Downs, C. \& Ktiri-Idrissi, L. (2014). Comparing South Texas and Qatari readers' responses to short stories from three cultures. Learning and Teaching in Higher Education: Gulf Perspectives, 11(2). http://lthe.zu.ac.ae 


\begin{tabular}{|lllllll|}
\hline & & & & & & reading. \\
Rashid & ENGIN & Pre & $18-22$ & Arabic-Eng & Muslim Arab & To make one a better reader \\
Suad & ENGIN & Pre & $18-22$ & Arabic & Muslim Arab & To prepare to enter university \\
Nour & BIOL & Pre & $18-22$ & Arabic & Muslim Arab & To train her to read properly \\
Nadia & COMM & Pre & $18-22$ & Arabic & Muslim Arab & Help with interpreting texts \\
\hline
\end{tabular}




\title{
Appendix B - Plot summaries of three short stories under study
}

\author{
"The Moths," by California Latina author Helena Maria Viramontes (1985).
}

The third-person narrator focuses on an independent fourteen-year-old girl in a traditional Latino family. The girl, teased by her sisters because of the size of her hands and punished by her father for refusing to attend Catholic mass, finds succor at the home of her grandmother, where she helps cook traditional meals and tend the garden. The grandmother enacts a traditional curing ceremony to reduce the size of her grand-daughter's hands.

Through the grandmother's final sickness, the role of caregiver is taken by the grand-daughter. At the story's dénouement, the grandmother dies of cancer at sunset. During her ritualistic washing of the body, the grand-daughter seems to become a more mature and wise caregiver, and in a magical transformation, a swarm of moths escapes from the grandmother's mouth and flies upward.

\section{"The Illusion," by Bahraini author Mohammed ‘Abd al-Malik (2005).}

As the story opens in a busy women's hospital in Bahrain, Hamid Faraj, the director-general, and his health-care staff are busy preparing to attend the wife of Su'ud al-Dhahab, who is of high social status, in childbirth. When Rashid 'Askar, a chauffeur, and his very pregnant wife arrive in a borrowed Mercedes-Benz automobile, the hospital staff assumes that she is the VIP they have been expecting, and the mother-to-be is hustled off to the delivery room and later to a private room, where no pains will be spared to fulfill her wishes.

Meanwhile, the real Su'ud al-Dhahab and his pregnant wife arrive. The hospital staff, realizing that they have made a mistake, hurry Rashid 'Askar and his wife out of the private room to something much less commodious, and show the VIP couple in, all smiles.

\section{"The Story of an Hour," by Missouri Irish-American author Kate Chopin (1894).}

The action of the short story happens within the span of one hour in New Orleans. Mrs. Mallard is a woman in a conventional nineteenth-century marriage who places her husband's needs above her own. When the short story opens, Mrs. Mallard learns of her husband's death in a railway accident. As she weeps in her bedroom alone, readers learn that Mrs. Mallard see-saws between mourning her husband's death and celebrating her own freedom.

Mrs. Mallard's sister, assuming wrongly that Mrs. Mallard will make herself ill with weeping, draws the new widow out of her room and down the stairs. As the sisters reach the bottom of the stairs, Mr. Mallard walks into the house, reports of his death having been mistaken. When Mrs. Mallard sees her husband alive, she falls dead of a heart attack as her short-lived freedom is taken from her.

\footnotetext{
${ }^{1}$ Although Gulf traditions include some narratives of magic, beyond a class discussion of folk-healing methods the students were not able to follow the magic theme any further.

${ }^{2}$ Six Kingsville students did not fill out the survey which explicitly gave consent to appear in this study, and one was under the age of consent. These seven students were omitted.

${ }^{3}$ In accordance with human subject protocol, all students' names have been changed with a name of the same gender. Spanish names have been replaced with Spanish names, English with English, and so on. Note that in South Texas, a given name inadequately expresses racial intermarriage of which the student may be a product.
} 
${ }^{4}$ Although the culture whose norm we attempted to pair with The Illusion is Gulf Arab, the Academic Bridge Program attracted students of varying ethnic backgrounds from all over the world. At least one of the listed students spent some years in the United States 